\title{
Improving Pigmented Rice Farmers' Marketing Activity for Sustainable Agroindustry: Consumers' Voice to be Considered
}

\author{
Shafira Wuryandani ${ }^{1, *}$, Dyah Ismoyowati ${ }^{1}$, Endy Suwondo ${ }^{1}$ \\ ${ }^{1}$ Department of Agroindustrial Technology, Universitas Gadjah Mada, Yogyakarta, Indonesia
}

\begin{abstract}
The demand for pigmented rice is highly increasing due to the consumer changing on a healthy lifestyle. The price of pigmented rice is higher than white rice, so it may be an opportunity to improve farmers' welfare. However, as producers, the farmers said they understand the consumer's needs and wants. They lack access to consumers' information. This article attempted to reveal the consumers' perspective of pigmented rice in Indonesia through their preferences and perceived quality. Those are variables indicating consumer voices. Two hundred sixty-one respondents are joining the survey from some big cities in Indonesia. The survey was exploring consumer voices about pigmented rice. The result shows that $83 \%$ of consumers said that pigmented rice is a superior product with a high price and high value. But the quality remains inconsistent, difficult to serve and combine with other dishes. The most attractive social media for them is Instagram Feeds. They often see the advertisement on social media and have more likely attracted by a campaign that been share on social media. Those help producers to market the rice better and broader, improving sustainable agroindustry on pigmented rice.
\end{abstract}

\section{Introduction}

Pigmented rice has an increasing demand every year. In 2017, based on Goldstein's research, demand for red rice and black rice will continue to grow over the next five years[1]. People can see the increase in demand for pigmented rice from its availability in traditional and modern markets[2]. Most consumers of pigmented rice consumed pigmented rice because of its nutritional content. The nutritional content of pigmented rice composed of anthocyanin, high fiber, and low sugar makes it a healthy food choice for consumers. As many as $75 \%$ of consumers stated that their motivation to consume pigmented rice is a health factor [3]. Those in line with Euromonitor's research that Indonesian consumers want to change their lifestyles to be healthier. Traditional diets high in cereal and plant products and traditional food practices continue to be dominant in both rural and urban areas, despite the context of rapid socioeconomic change and urbanization [4]. This pigmented rice is one way to change consumption patterns towards a more beneficial direction [5].

\footnotetext{
* Corresponding author: shafirawuryandani@gmail.com
} 
The pigmented rice market is a niche market that has the potential to be expanded. This is an opportunity for farmers to sell more valuable products at a higher price. However, from the farmers' point of view, they admitted that it is difficult to market pigmented rice [2]. Most farmers market the pigmented rice in bulk, not with certain brands, and have not targeted the retail market [6].

Those happened because farmers do not have access to market information. Previous research in Surakarta also revealed the need for a marketing strategy for red rice by producers. Red rice consumers in Surakarta do not feel that the brand among red rice is significantly different. Those need to be a concern for producers to implement red rice's marketing strategy [6] actively. Farmers did not know who and how consumers preferences on pigmented rice. This article aims to find out the perspective of pigmented rice consumers and how their preferences. The results of this study can be used as inputs for farmers to improve their marketing activity. This market information will support a more sustainable, pigmented rice business.

\subsection{Pigmented rice}

Rice, one of the main foods of most of the world's population, has a role in fulfilling the number of antioxidants that must be consumed, especially in red and black rice. Pigmented rice has a low GI and high antioxidant properties and more nutritional potential than white rice. Even the nutritional composition of pigmented rice would be a better ingredient for the food industry [7]. People know black rice for a long time as a food and as a medicinal. Anthocyanins and other interesting bioactive compounds in black rice exhibit high antioxidant activity and involve as preventive agents for various diseases such as cancer [8]. The pigmented pericarp of rice contains a high content of phenolic compounds, including anthocyanins that give color pigments in red rice and black rice [9]. Anthocyanin color pigment, which has high intensity, will make the rice color dark purple to black in black rice. Black rice can be a source of anthocyanins, which can function as antioxidants. Apart from being high in antioxidants, pigmented rice also contains more fiber but contains less sugar[9].

Black rice and red rice are easily found in Asia, India, China, and Indonesia [10]. Those are called pigmented rice, which are healthy foods native to Indonesia. Most pigmented rice producers come from several Indonesia regions, such as Yogyakarta and Central Java, and some regions outside Java. Pigmented rice have anthocyanin pigments outside to have a deep black and red color. Pigmented rice is popular in Asia, from India, China to Indonesia. Black rice has many other names, such as emperor rice and forbidden rice[10].

Some experts claim that pigmented rice is much healthier than white rice. Pigmented rice varieties are rich in phenolics and anthocyanins [9]. Red rice contains anthocyanins, which are antioxidants. Anthocyanin compounds can reduce inflammation, allergies, lower cancer risk, and help with weight loss. Red rice is often recommended for consumption by people with diabetes and heart disease. The red rice content can reduce arterial plaque, prevent cardiovascular risk, lower high cholesterol, and reduce the risk of diabetes. Black rice has better nutritional content than red rice and red rice. Black rice contains fiber, antioxidants, phytonutrients, vitamin $\mathrm{E}$, protein, iron, and other nutrients. Black rice is considered by experts to have benefits for the liver, kidneys, and stomach and recommend black rice for people with heart disease, diabetes, and high blood pressure[8]. 


\subsection{Consumer preferences}

Consumer behavior includes planning, purchasing, and using a product or service of economic value. Consumer behavior is dynamic because consumers always change and move based on the function of time. This dynamic nature causes no effective marketing strategy at all times in the same market and industry. Consumer behavior, cognitive factors, influences, and behavior of consumers need to be understood. The starting point for understanding consumer behavior is the stimulus-response model. Emotional, functional, social, epistemic, and conditional values can influence the value trade-offs that consumers make during the decision to either retain an owned product or replace it with a new one[11].

The main factors that affect consumer buying behavior are Personal factors, Psychological aspects, Social Factors, and Economic factors. A consumer with different ages, life cycle stages, motivation, and perceptions affects the consumer's buying behavior and surroundings and plays a significant role in influencing the buying decision [12]. Attitudes tend to accept or reject something based on their experiences to behave in a consistently beneficial or unfavorable manner to an object. The object referred to in the definition of consumer orientation includes things that represent consumption or related to marketing. The items referred to have products, types of products, brands, services, ownership, use of products, cases or issues, society, advertisements, internet sites, prices, retailers, and so on. As learned predisposition, the philosophy has relevance to buying behavior formed from direct experience with products, advertisements, the internet, and various forms of direct marketing. Attitudes can be the result of the action, but the perspective is not the same as behavior. Another characteristic of philosophy is consistency. The attitude is relatively consistent with the behavior reflected by consumers. However, even though attitudes and behaviors have consistency, attitudes are not always permanent. Attitudes can change. Attitudes can be influenced by situations that change the relationship between attitude and behavior at a certain point. A specific problem can make a consumer have an inconsistent attitude with his behavior [13].

\section{Methods}

Rice consumers are the respondent in this research survey conducted in February - March 2020. The respondents are consumers who had purchased rice in Jakarta, Bandung, Surabaya, Yogyakarta, and Bali. These cities are significant in Indonesia, where most of Indonesia's population lives. Most of those cities are urban areas where economic dimensions and modern healthy lifestyles influenced urban upper classes [14].

Respondents answer some questions in an online survey to reach broader consumers. An online survey is a recommended survey method to obtain large amounts of data in a relatively shorter time than offline surveys. The sample is determined by the convenience sampling method.

Respondents accept questionnaires distributing through social media. Several statements and scale statements related to the quality factors of pigmented rice and the media are looking for product information on the survey. The pigmented rice quality factors in question were the consistency of product quality, product durability, price, taste, ease of serving, and product superiority. The promotion media section contains statements describing consumer perceptions of pigmented rice promotion media. The choice "strongly disagree" has a value of 1 point, "disagree" has a value of 2 points, "agree" has 3 points, and "strongly agree" has 4 points. Table 2 shows the mean of each statement. The collected data was analyzed qualitatively. Some data were analyzed quantitatively with descriptive statistics to determine the average answer and the percentage of consumers' perspectives. 


\section{Results and Discussion}

\subsection{Respondent profile}

Table 1 displays the characteristics of the respondents. Of the 261 respondents obtained, $71 \%$ were women, aged $22-26$ years, $45 \%$ had single marital status, $32 \%$ worked in the private sector, $33 \%$ had a monthly income of 2.5 million - 5 million rupiah (around USD170 - USD340).

Table 1. Respondent profile.

\begin{tabular}{|c|c|c|c|}
\hline Socio-demographic characteristic & Category & $\mathbf{n}$ & $\begin{array}{c}\text { Percent } \\
(\%)\end{array}$ \\
\hline \multirow{2}{*}{ Gender } & Male & 75 & $35 \%$ \\
\hline & Female & 186 & $86 \%$ \\
\hline \multirow{9}{*}{ Age } & $17-21$ & 27 & $13 \%$ \\
\hline & $22-26$ & 104 & $48 \%$ \\
\hline & $27-31$ & 51 & $24 \%$ \\
\hline & $32-36$ & 20 & $9 \%$ \\
\hline & $37-41$ & 15 & $7 \%$ \\
\hline & $42-46$ & 13 & $6 \%$ \\
\hline & $47-51$ & 11 & $5 \%$ \\
\hline & $52-56$ & 12 & $6 \%$ \\
\hline & $57-61$ & 9 & $4 \%$ \\
\hline \multirow{2}{*}{ Marital status } & Single & 116 & $54 \%$ \\
\hline & Married & 100 & $46 \%$ \\
\hline \multirow{8}{*}{ Monthly income (Indonesian Rupiah) } & $<$ IDR 1 million & 42 & $19 \%$ \\
\hline & $\begin{array}{l}\text { IDR } 1 \text { million - IDR } 2.5 \\
\text { million }\end{array}$ & 47 & $22 \%$ \\
\hline & $\begin{array}{l}\text { IDR } 2.5 \text { million - IDR } 5 \\
\text { million }\end{array}$ & 85 & $39 \%$ \\
\hline & $\begin{array}{l}\text { IDR } 5 \text { million - IDR } 7.5 \\
\text { million }\end{array}$ & 30 & $14 \%$ \\
\hline & $\begin{array}{l}\text { IDR } 7.5 \text { million - IDR } 10 \\
\text { million }\end{array}$ & 26 & $12 \%$ \\
\hline & $\begin{array}{l}\text { IDR } 10 \text { million - IDR } 15 \\
\text { million }\end{array}$ & 17 & $8 \%$ \\
\hline & $\begin{array}{l}\text { IDR } 15 \text { million - IDR } 30 \\
\text { million }\end{array}$ & 11 & $5 \%$ \\
\hline & $>$ IDR 30 million & 3 & $1 \%$ \\
\hline \multirow{5}{*}{ Place of resident } & Yogyakarta & 94 & $44 \%$ \\
\hline & Jakarta & 60 & $28 \%$ \\
\hline & Bali & 31 & $14 \%$ \\
\hline & Surabaya & 39 & $18 \%$ \\
\hline & Bandung & 37 & $17 \%$ \\
\hline \multirow{4}{*}{ Rice consumption } & White rice & 168 & $78 \%$ \\
\hline & Red rice & 75 & $35 \%$ \\
\hline & Black rice & 6 & $3 \%$ \\
\hline & Mixed & 12 & $6 \%$ \\
\hline
\end{tabular}

Besides, $25 \%$ of respondents admitted to regularly consuming pigmented rice. $75 \%$ of respondents said that they did not consume pigmented rice regularly. Those difference is statistically significant $(\mathrm{F}=1.277$, Sig. 0.260). The survey showed that most of the respondents $(64 \%)$ consumed white rice. The others are consuming red rice $(29 \%)$, black rice $(2 \%)$, or mixed rice $(5 \%)$, which consist of pigmented rice and white rice. 


\subsection{Consumers perspective on the quality of pigmented rice}

The survey revealed the perception of the quality of pigmented rice according to consumers. Perception of rice quality may refer to grain quality traits such as color, cleanliness, purity, grain shape and size, uniformity of size and shape, head rice (HR), softness, and aroma. At the same time, extrinsic attributes include packaging, labeling, and branding [15]. This perceived quality describes the product performance that consumers have in mind. It means that the perceived quality is better than the actual quality. According to consumers, pigmented rice is a perishable product. Pigmented rice is more susceptible to attack by rice fleas (Sithopylus oryzae). White rice is more resistant to Sitophilus oryzae beetle attack, which causes rice damage compared to brown rice and black rice [16]. For this reason, consumers need detailed information on how to store pigmented rice on the packaging so that pigmented rice's durability is longer.

In terms of price, pigmented rice has a higher price than white rice. Pigmented rice ranges in price from IDR 28,000 - IDR 38,000 per $\mathrm{kg}$. The price of pigmented rice can reach $200-300 \%$ more than white rice [2]. Even though the price is higher than white rice, consumers' willingness to pay for black rice is around IDR 29,000, while the willingness to pay for red rice was IDR 33,350 per kilogram [17]. On both red and black rice, the highest farmer's share was when on the chain that consisted of the farmer, distributor, and end-user consumer [18]. Even though the price is high, the price of pigmented rice tends to be consistent. The price of pigmented rice rarely fluctuates like other staple foods. Some factors influence rice prices. Grain quality, gel consistency, household per capita rice consumption, and other socioeconomic factors affect rice prices [19].

Most consumers felt that this rice is difficult to serve. Consumers said that they could only combine pigmented rice with individual side dishes. Pigmented rice is known to have a less delicious taste and texture than white rice, following the survey results where most of the respondents did not like the taste and texture.

The result shows that $83 \%$ of consumers said that pigmented rice is a premium product with a high price and high value. It can be seen by most respondents who state that they agreed about the superiority factors that pigmented rice has. The majority of consumers are willing to say that this pigmented rice has product advantages. Most consumers see pigmented rice as high in fiber and low in sugar. Some of them can even mention the anthocyanin content in pigmented rice. Pigmented rice is known as a functional food for consumers in Indonesia. Most pigmented rice consumers had healthy motivation when they consumed pigmented rice. Some of the consumers said that consuming pigmented rice can help them to lose weight. They believe the lower glycemic index in pigmented rice can help them lose weight [3].

\subsection{Promotion media preferences}

In this study, the promotion media, which is the consumer's preference, were investigated. The consumer got asking about four media. The four media are advertisements, word of mouth, campaigns, and information on packaging. These promotion media are determined based on some literature, which states that those promotion media positively affect consumer brand awareness and brand loyalty. Those are important because brand awareness and consumer brand loyalty will build sustainable consumption, which means that pigmented rice farmers have the opportunity to produce and sell more. Promoting food production of sustainable issues within the brand also creates sustainable awareness through the consumers to help farmers market [20]. 
Table 2 shows the survey results. Each marketing medium is calculated on average and its standard deviation. The percentage of each statement item is also estimated to see which promotion media with the highest preference.

Table 2. Promotion media preference based on a survey (primary data).

\begin{tabular}{|c|c|c|c|}
\hline Subsections & items & $\begin{array}{l}\text { Mean } \\
\text { score }\end{array}$ & $\begin{array}{c}\text { Percentage } \\
\text { of agreed } \\
\text { consumers }\end{array}$ \\
\hline \multirow{4}{*}{ Advertisement } & Advertisements always provide new product information & 2,78 & $74 \%$ \\
\hline & $\begin{array}{l}\text { The message conveyed in the advertisement aroused my } \\
\text { desire to know more about the rice products I consume. }\end{array}$ & 2,70 & $68 \%$ \\
\hline & $\begin{array}{l}\text { The message conveyed in the rice advertisement } \\
\text { influenced my decision to determine which rice I would } \\
\text { consume. }\end{array}$ & 2,56 & $57 \%$ \\
\hline & Subsection mean & 2,68 & $66 \%$ \\
\hline \multirow{8}{*}{$\begin{array}{l}\text { Word of } \\
\text { Mouth }\end{array}$} & I got information on pigmented rice from a friend & 2,59 & $61 \%$ \\
\hline & My friend persuaded me to consume pigmented rice & 2,11 & $21 \%$ \\
\hline & $\begin{array}{l}\text { I got clear information about pigmented rice from a } \\
\text { friend }\end{array}$ & 2,34 & $42 \%$ \\
\hline & $\begin{array}{l}\text { I got convincing information about pigmented rice from } \\
\text { a friend }\end{array}$ & 2,32 & $38 \%$ \\
\hline & $\begin{array}{l}\text { I got information about pigmented rice from trusted } \\
\text { people }\end{array}$ & 2,70 & $67 \%$ \\
\hline & $\begin{array}{l}\text { The information provided by a person I trust created a } \\
\text { desire to consume pigmented rice }\end{array}$ & 2,65 & $63 \%$ \\
\hline & $\begin{array}{l}\text { I buy based on the popularity of the type of rice I } \\
\text { consume }\end{array}$ & 2,28 & $33 \%$ \\
\hline & Subsection mean & 2,43 & $46 \%$ \\
\hline \multirow{4}{*}{ Campaign } & The call moved me for a low sugar diet & 2,94 & $78 \%$ \\
\hline & I'm interested in the invitation to a low carb diet & 2,89 & $74 \%$ \\
\hline & $\begin{array}{l}\text { I am not interested in the invitation to exercise for at } \\
\text { least } 30 \text { minutes a day }\end{array}$ & 2,25 & $36 \%$ \\
\hline & Subsection mean & 2,69 & $62 \%$ \\
\hline \multirow{4}{*}{ Packaging } & $\begin{array}{l}\text { I bought the product because the packaging was } \\
\text { attractive }\end{array}$ & 2,44 & $46 \%$ \\
\hline & $\begin{array}{l}\text { I prioritize products that have environmentally friendly } \\
\text { packaging }\end{array}$ & 2,97 & $82 \%$ \\
\hline & $\begin{array}{l}\text { I pay close attention to detailed information regarding } \\
\text { the products listed on the packaging }\end{array}$ & 2,89 & $77 \%$ \\
\hline & Subsection mean & 2,77 & $68 \%$ \\
\hline
\end{tabular}

Based on the consumer survey, advertising ranks first as a medium that favors consumers in seeking information related to new products. Marketer in Indonesia rarely brings advertisements for rice products. Those are unique insights where farmers or pigmented rice producers can carry out advertisements to disseminate their products. It is essential because many consumers do not know about red rice and black rice products. Detailed and persuasive information also needs to be displayed in advertisements so that consumers are aware of and understand the nutritional content and benefits of consuming pigmented rice. 
Advertising for consumers is a medium for obtaining information about products. The message conveyed in the advertisement can arouse consumers' desire to know more about pigmented rice products. Even messages in advertisements can influence consumers' decisions to determine what kind of rice they will consume. There are $61 \%$ of members of this consumer group who agree with this.

In this digital era, producers of pigmented rice can do advertising through many media accessible to producers of pigmented rice. Advertising through social media can be a way for producers to provide product information to consumers. An advertisement has a significant impact on consumer buying behavior through various media such as newspapers, magazines, outdoor ads, blogs, and websites [21]. Social media users find social media ads useful and personalized, and that the perceived usefulness and personalization significantly affect the usage of host architecture, which significantly affects users' experience [22]. However, it does not rule out advertisements through digital media, considering that digital media can easily reach more consumers. Advertising in social media should show an image or a video ad. In composing a video ad, it should be 1 minute long. This duration is crucial for stealing consumers' attention based on social media user research [23]. As many as $66 \%$ of members of these respondents are interested in product information displayed in advertisements. They even have an interest in buying a product after seeing an ad.

The media word of mouth that producers can do is to take advantage of friends and family circle. Friends are the main source of consumers to obtain product information before deciding to buy. As much as $55 \%$, most consumers admit that they feel confident and trust the information related to their friends' rice products. However, in the overall survey results, word of mouth has the lowest value, namely $53 \%$, so that in the model, it has the smallest weight as well. Those cause the media of word of mouth to become a medium that can be eliminated from the available options if the resulting producer does only three ingredient branding media. Word of mouth is one way that can do to increase brand awareness and brand recall for rice consumers [24]. The word of mouth strategy can also do for Indonesian consumers, especially through the closest circle of consumers, family, friends, and relatives.

Campaigns are also media that needs to do to increase consumer loyalty. Health-related campaigns are quite influential in increasing consumer loyalty for products that have health benefits. This media is often used for marketing functional food products. According to the survey results, $62 \%$ of consumers are attracted by the call for low sugar, low carbohydrate diet. It is consistent with pigmented rice products, which contain a glycemic index, an indicator of the sugar content in food, lower than white rice. This group's consumers are also interested in doing regular exercise, which indicates a healthy lifestyle.

The campaign can be carried out by linking a healthy lifestyle with the consumption of pigmented rice. Diet-related campaigns promote healthy living to become a suitable marketing medium for healthy food [25]. According to other research, this makes healthy food branding one of the rice marketing strategies [3]. Besides, healthy communities can also be a medium for disseminating information and campaigns to new consumers. Advertising and campaigns by presenting healthy messages to adults influence to change healthier food choices [26]. Pigmented rice could help the campaign about reducing highsugar foods for diabetes mellitus. Campaigns for consumer groups who wish to obtain other micronutrients from their rice can market pigmented rice. Other campaigns in the form of an invitation to live healthily and consume pigmented rice can also be conducted. However, an effective health-related campaign should not be confusing for consumers. The expert suggested effective messaging that addressed the eating pattern and emphasizing nutrient content [27]. 
The packaging is the most widely used branding medium. As many as $68 \%$ of consumers agree that packaging is a factor that attracts their purchases. Consumers agree that they buy products with attractive packaging. They also prioritize environmentally friendly packaging. Besides, complete packaging information related to products is attractive to consumers. This group of consumers mostly agreed that they paid attention to the detailed product information contained in the packaging. Provide complete information on pigmented rice packaging. Packaging that contains product information is crucial for consumers. Information on the packaging shows all things related to packaging that are important for consumers to know and can make them interested in consuming. This informative packaging is also an important aspect for consumers of pigmented rice in Yogyakarta [3]. Millennial consumers who have a healthy lifestyle pay attention to the information on the packaging. They read the detailed information written on the packaging. Based on observations, packaging, and information on the package confirm the role of extrinsic quality cues in building value for the product [15]. The form of packaging also becomes a consumer focus. Rice packaging with an upright pouch equipped with a zipperlock is popular with pigmented rice consumers in Yogyakarta compared to other packages [28]. The packaging information must contain information on storing it, how to serve it, and the nutritional content. How to store pigmented rice is important to mention on the packaging label. It is because pigmented rice has characteristics that are easily damaged and susceptible to ticks when placed at room temperature. How to serve pigmented rice also needs to be informed about serving rice into the rice and combining pigmented rice with certain vegetables or side dishes. Those, of course, will greatly help consumers, especially new consumers. Information regarding the nutritional content of pigmented rice also needs to be displayed to convince consumers that this pigmented rice has nutrients that are beneficial to consumer health, such as branding carried. Producers need to highlight the nutritional content: anthocyanin, sugar content, fiber content, and antioxidants.

\subsection{Social media preferences}

Due to the increase in internet use, e-commerce and social media play an essential role in consumer buying behavior. E-commerce is where consumers make purchases more often every time, and the study of consumer behavior should provide new theories or improve before predicting consumers' decisions [29]. Many marketers have used the use of social media for marketing activity. As technology advances, various kinds of social media have emerged. Research revealed that $70 \%$ of adult people engaged with food brands on social media [30]. Based on the survey results, Figure 1 shows the social media that consumers use most often. Most consumers choose WhatsApp and Instagram as the social media they use frequently. However, the most engaging social media for consumers, especially to find out about products, is Instagram Feeds. This medium has the most number of interests shown in Figure 2. 


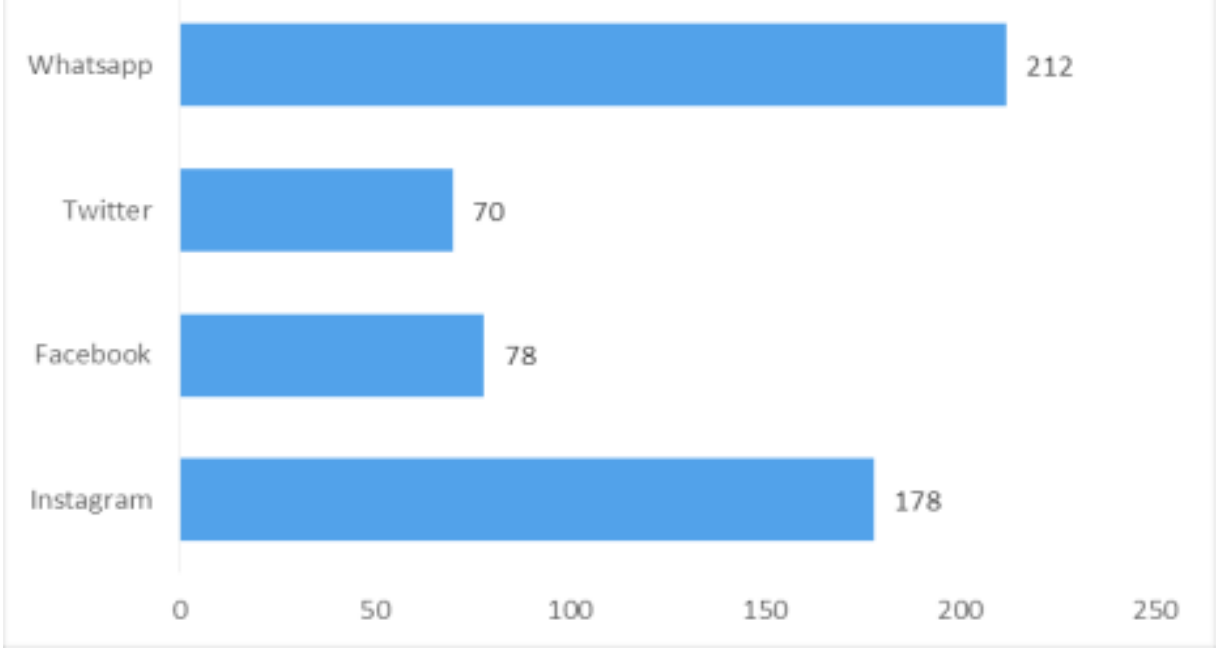

Fig. 1. Social media that consumers use most often (Source: primary data)

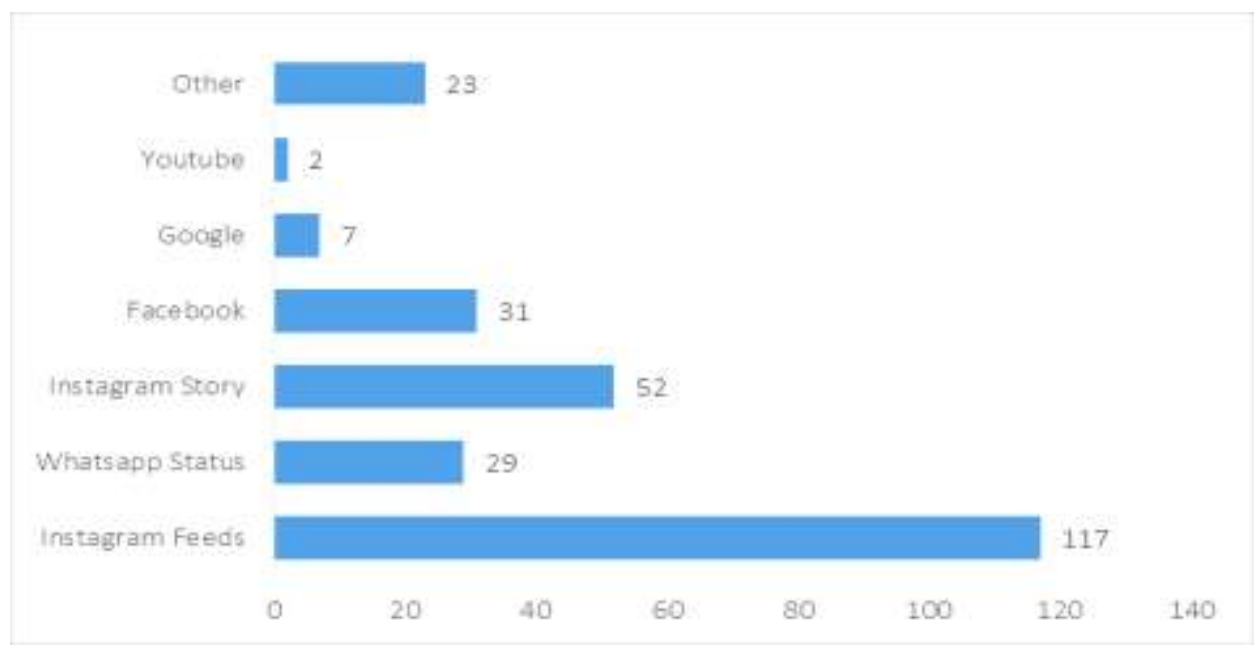

Fig. 2. Social media that attracted the most consumer (Source: primary data)

Based on the survey, $52 \%$ of consumers can buy products advertised on social media. As many as $71 \%$ of them also testified that they often see advertisements on social media. However, only $58 \%$ of consumers have ever bought products advertised on social media. There are various forms of social media ads, including ads in collaboration with platforms, ads through social media influencers. Advertising through social media influencers aims to form a positive image of the product to see its positive feelings. Those will then encourage consumers to purchase products [31]. We often see these social media influencers in the form of public endorsement of figures. Social Media Influencer (SMI) shaped positive emotion and positively influenced their followers through brand recommendation[31]. Pigmented rice can adapt this to increase consumer interest. Public figures who are aware of healthy food and healthy lifestyles can carry out the endorsement. They can deliver the message that this pigmented rice has anthocyanin pigments that affect health to potential consumers. 
As many as $70 \%$ are interested in the health-related campaign on social media. Social media use to disseminate healthy living campaigns can positively influence nutritional products in the United States. Health campaigns have a lower investment value than advertisements or other promotion media but provide significant results for brands that do [25]. Social media's health-related campaign can reach youth to persuade them to adopt specific health messages or behavior [32]. The day's need is to aggressively market pigmented rice and promote them through greater public awareness about their importance, especially among the younger generation. Clinical validation of medicinal value is necessary to establish a niche in the global market [33].

\section{Conclusion}

This survey has revealed consumers' voices about pigmented rice. Consumers are willing to buy at a premium even though they don't like the taste or texture of pigmented rice. They continue to consume the product's superiority from its nutritional content, which affects their health. It is an opportunity for farmers, as producers, to market pigmented rice to consumer groups aware of their health.

Promotion media that are attractive to pigmented rice consumers are advertisements, health-related campaigns, and information on packaging. Word of mouth can be an excellent medium to disseminate pigmented rice products to consumers who are not familiar with pigmented rice. However, word of mouth is a medium that occurs among consumers, mostly through friends or family of consumers, not directly carried out by producers.

In the current era, consumers have relatively free access to social media. Social media can be a producer channel in conducting health-related advertisements and campaigns. Surveys show that consumers often see ads on social media. Some of them even bought products because they saw advertisements on social media. For most consumers in this survey, Instagram Feeds is one of the most attractive social media for them to access information search for rice products. They also use social media to find the benefits of a product for their health. The majority of them are also motivated to participate in campaigns related to healthy lifestyles spread through social media. These suggestions can be taken into consideration by pigmented rice producers for their marketing activity. The use of social media for marketing can also expand the network of the pigmented rice market. Smooth marketing activities will undoubtedly help pigmented rice farmers to realize sustainable pigmented rice agroindustry.

The RTA Program under The Directorate of Research UGM supported thus research to DI and SW.

\section{References}

1. Goldstein, Indonesia Rice Market Outlook, Research Report: Industry Analysis, Size, Trends, Growth, Share, Demand, Segmentation, Market Overview, \&amp; Forecast 2017-2025 (Jakarta, 2018).

2. T. R. Nuringtyas and D. Ismoyowati, Agric. Dev. Notes 8, (2018).

3. S. Wuryandani, D. Ismoyowati, and A. D. Nugrahini, KnE Life Sci. 4, 128 (2018).

4. D. Colozza and M. Avendano, Soc. Sci. Med. 233, 103 (2019).

5. Euromonitor Indonesia, Consumer Lifestyle in Indonesia (2018).

6. A. A. Putri, D. Ismoyowati, and A. P. Pamungkas, in IOP Conf. Ser. Earth Environ. Sci. (Institute of Physics Publishing, 2019). 
7. K. Meera, M. Smita, S. Haripriya, and S. Sen, J. Cereal Sci. (2019).

8. V. C. Ito and L. G. Lacerda, Food Chem. 301, (2019).

9. J. Ratseewo, F. J. Warren, and S. Siriamornpun, Food Chem. 298, (2019).

10. T. Oikawa, H. Maeda, T. Oguchi, T. Yamaguchi, N. Tanabe, K. Ebana, M. Yano, T. Ebitani, and T. Izawa, Plant Cell 27, 2401 (2015).

11. R. van den Berge, L. Magnier, and R. Mugge, Curr. Opin. Psychol. 39, 66 (2021).

12. S. Qazzafi, Int. J. Sci. Res. Dev. 8, (2020).

13. L. G. Schiffman and J. L. Wisenblit, Consumer Behavior, Eleventh Edition (2015).

14. F. S. Seda, L. Setyawati, T. Tirta, and K. Nobel, Data Br. 31, (2020).

15. M. C. Custodio, R. P. Cuevas, J. Ynion, A. G. Laborte, M. L. Velasco, and M. Demont, Trends Food Sci. Technol. 92, 122 (2019).

16. Y. W. Harinta, J. AGROVIGOR (2016).

17. Y. R. Putri, D. Ismoyowati, and Jumeri, in IOP Conf. Ser. Earth Environ. Sci. (Institute of Physics Publishing, 2019).

18. K. P. Anindita, D. Ismoyowati, and E. Suwondo, AgriTECH 39, 315 (2019).

19. R. P. Cuevas, V. O. Pede, J. McKinley, O. Velarde, and M. Demont, PLoS One 11, (2016).

20. S. Franco and C. Cicatiello, Ref. Modul. Food Sci. Encycl. Food Secur. Sustain. 3, 27 (2019).

21. T. Haider and S. Shakib, Bus. Stud. J. (2017).

22. D. A. Al Qudah, B. Al-Shboul, A. Al-Zoubi, R. Al-Sayyed, and A. I. Cristea, Heliyon 6, (2020).

23. S. Isabella, (2019).

24. L. M. Kathuria and P. Gill, Br. Food J. 115, 1255 (2013).

25. T. R. Englund, M. Zhou, V. E. Hedrick, and V. I. Kraak, J. Nutr. Educ. Behav. 52, 87 (2020).

26. T. M. Dovey, T. Torab, D. Yen, E. J. Boyland, and J. C. G. Halford, Appetite (2017).

27. S. Gonzales-Nahm, A. M. Bhatti, M. L. Ames, D. Zaltz, and S. E. Benjamin-Neelon, J. Nutr. Educ. Behav. 595 (2020).

28. Y. R. Putri and D. Ismoyowati, in IOP Conf. Ser. Earth Environ. Sci. (Institute of Physics Publishing, 2020).

29. N. Pena-Garcia, I. Gil-Saura, A. Rodriguez-Orejuela, and J. R. Siquera-Junior, Heliyon 6, (2020).

30. F. Fleming-Milici and J. L. Harris, Appetite 146, (2020).

31. C. W. 'Chloe' Ki, L. M. Cuevas, S. M. Chong, and H. Lim, J. Retail. Consum. Serv. (2020).

32. S. H. Ayub, Y. Manickam, M. R. Hamzah, J. Suanda, and H. A. Mohd Yusoff, SHS Web Conf. (2017).

33. A. T. and D. S. Prabha R Chaudhari, Nishesh Tamrakar, Laxmi Singh, J. Pharmacogn. Phytochem. (2018). 